\title{
O RESSURGIMENTO DO PIRARUNGÁUA: \\ CAMINHOS E DESCAMINHOS DAS ÁGUAS URBANAS
}

THE RESURGENCE OF PIRARUNGÁUA: UPS AND DOWNS OF URBAN WATERS

\author{
Juliana Maria de Souza Freitas ${ }^{1}$ e Maria de Assunção Ribeiro Franco² \\ ${ }^{1}$ Mestranda FAUUSP, área de concentração Paisagem e Ambiente \\ Arquiteta e Urbanista formada pela EESC/USP \\ E-mail: ju.freitas@usp.br / julianafreitas@santos.sp.gov.br \\ orcid.org/0000-0003-0525-0095 \\ ${ }^{2}$ Arquiteta, Professora Titular na Faculdade de Arquitetura e Urbanismo da \\ Universidade de São Paulo, São Paulo, SP. \\ E-mail: mariafranco@usp.br \\ orcid.org/0000-0001-9679-8552
}

\section{RESUMO}

O presente trabalho busca promover a reflexão a respeito das transformações na relação das cidades com seus rios, relação esta moldada a partir do sistema de crenças e valores de cada época. Para isso constrói um breve panorama da evolução da dialética rios-sociedade no intuito de compreender o ambiente com sua historicidade e explora dois estudos de casos, sendo o primeiro sobre o córrego Cheong-Gye, em Seul, Coréia do Sul, e o segundo, o córrego Pirarungáua, em São Paulo, Brasil. Como critério para a escolha dos casos, optou-se pela diversidade, tanto em relação aos motivos que nortearam o projeto, quanto ao seu caráter e contexto de inserção urbana.

Palavras-chave: Rios Urbanos; Córrego Pirarungáua; Córrego Cheong-Gye; Relação rios-cidades

\section{ABSTRACT}

The present work aims to promote the reflection about the transformations in the relation of cities and their rivers. These relations are based on the system of beliefs and values of each particular period. Aiming to do so, a brief overview of the evolution of 
the river-society dialectic is built in order to understand the environment with its historicity and explores two case studies, the first about the Cheong-Gye Stream in Seoul - South Korea - and the second, the Pirarungáua Stream, in São Paulo - Brazil. As a criterion for the choice of cases, diversity was chosen, either in relation to the reasons that guided the project, as well as its character and context of urban insertion.

Keywords: Urban Rivers; Pirarungáua Stream; Cheong-Gye Stream; River-city relationship

\section{INTRODUÇÃO}

Como fonte de água, elemento indispensável e em cujas proximidades estabeleceram-se as primeiras cidades, ou como elementos simbólicos na paisagem, que estruturam o território ocupado; os rios têm acompanhado o homem ao longo de toda a sua trajetória existencial. Essa relação, harmônica no início, como pode ser constatada através da história dos assentamentos junto aos vales férteis na antiguidade, evoluem até a completa negação das águas urbanas, que em muitos casos correm esquecidas e poluídas sob os eixos viários.

Os problemas atribuídos atualmente aos fluxos fluviais urbanos são decorrentes de dois fatores principais. O primeiro caracteriza-se pelo reflexo das ações antrópicas no território, ou seja, desmatamento, impermeabilização do solo, canalização e retificação de rios e córregos, ocupação de várzeas, entre outros. O segundo, diretamente relacionado ao primeiro, diz respeito à concepção de corpos hídricos como um elemento linear visível, quando na verdade é preciso considerar a lógica territorial de toda a área de escoamento. Assim, rios e bacias hidrográficas ${ }^{1}$ constituem elementos básicos e essenciais da estrutura hidrológica do território (SARAIVA, 1999).

\footnotetext{
1 Saraiva (1999) entende a bacia hidrográfica como sendo um sistema onde os recursos "água" e "solo" se estruturam mutuamente na organização da paisagem. A primeira, por sua vez, entendida como a face visível e sensorial do território, passível de compreensão analítica e indutora de sensações cognitivas e estéticas.
} 
Mas os rios, elementos tão comuns e ao mesmo tempo tão singulares, são muito mais que um conjunto de características físicas atreladas a um território, são importantes elos entre Natureza e Homem, onde a dicotomia entre sistemas naturais e sistemas humanizados será sempre expressa por meio do sistema de crenças e valores de uma determinada época.

Nesse sentido, Bethemont (1993) afirma que "se o rio é o espelho dos tempos em uma determinada sociedade, é também um reflexo de diferenciações espaço-culturais, pois muitas sociedades baseiam seus valores permanentes e fundamentais em suas águas"2 (BETHEMONT,1993, apud SARAIVA, 1999, p. 48). Burle Marx (2004) também coaduna com este pensamento ao afirmar que o aparecimento da civilização é marcado pela interferência consciente na paisagem natural, transformando-a em paisagem construída, na qual são incorporados conceitos éticos (políticos e religiosos) e estéticos (forma, material e estilo) presentes na cultura de cada sociedade num determinado momento histórico.

\section{AS CIDADES E SEUS RIOS - BREVE HISTÓRICO}

A história dos rios está entrelaçada à história da humanidade desde os primórdios da existência humana. Estabelecendo com o entorno uma relação de sobrevivência, várias sociedades floresceram baseadas na irrigação de campos agrícolas, a exemplo da civilização babilônica e egípcia, entre tantas outras (Figuras 01 e 02). Nessa época, o rio além de provedor ainda possuía um caráter mitológico associado a seus fluxos e ciclos (SARAIVA, 1999).

Segundo Saraiva (1999), nas civilizações do mundo antigo o rio não é referido apenas como elemento estruturador do espaço, mas também carrega o simbolismo do sagrado e do profano, do puro e do impuro ${ }^{3}$. Para a autora, a origem dos mitos está associada à ocorrência de eventos extremos que interferiam nos fluxos das águas

2 Cf. original "Si le fleuve constitue bien le miroir des temps que connaît une societé donnée, il est également le reflet des différenciations spatio-culturelles, nombre de societés fondant leurs valeurs permanentes et fondamentales sur leurs eaux." (BETHEMONT,1993, apud SARAIVA, 1999, p. 48, tradução nossa).

3 Muitos destes simbolismos perduram até os dias atuais, como por exemplo o batismo (rito de purificação) e a crença no dilúvio bíblico (mito da punição). 
como, por exemplo, cheias e estiagens. Com o intuito de controlar esses fenômenos, em especial os primeiros, iniciou-se a prática de manipulação da natureza através do desenvolvimento de técnicas evoluídas de jardinagem e de regularização fluvial. Tem início, assim, a transformação da paisagem pelas mãos do homem.

Diante do exposto, é possível aferir a importância dos sistemas hídricos para os assentamentos humanos e que, em decorrência dessa simbiose, rios e córregos têm sido fortemente transformados desde a época em que o homem deixou para trás a vida nômade. Assim, a história das águas se confunde com a ambição humana em controlar os padrões temporais e espaciais de disponibilidade de água, sendo tanto uma história social quanto tecnológica (SARAIVA, 1999). Muitos são os exemplos que vêm ao encontro de tal afirmação, do desvio de águas de córregos e rios para abastecer fontes e canais de irrigação a construção de aterros para plantio.

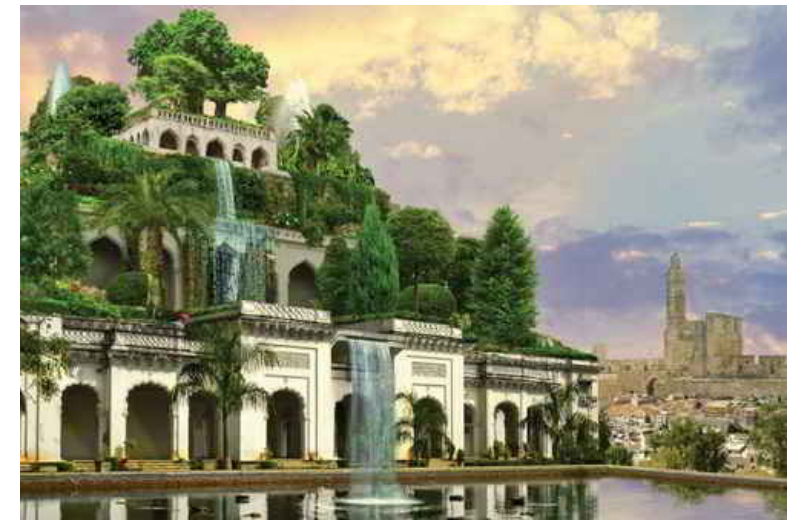

FIGURA 01. Jardins suspensos da Babilônia. Fonte: People and Countries (2015).

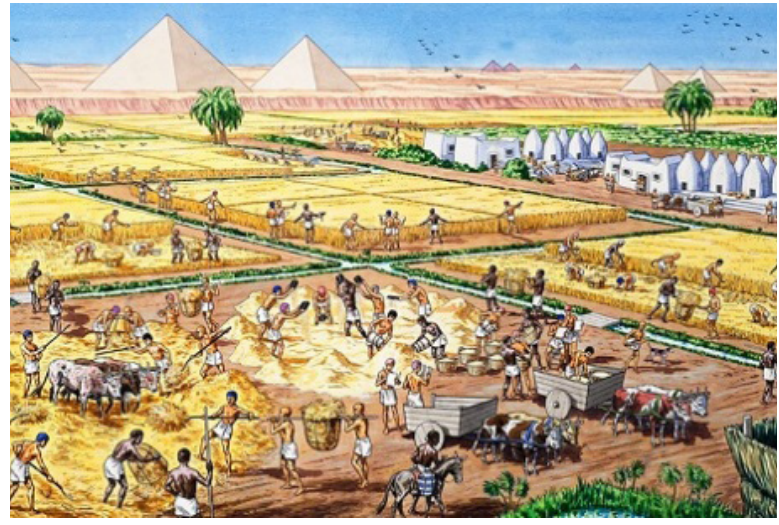

FIGURA 02. Canais de irrigação no antigo Egito. Fonte: Blog Amigo Pai (2015).

Atualmente, no entanto, tais intervenções assumem dimensão e relevância ímpares. De acordo com Saraiva (1999), quase todos os grandes rios da Europa foram canalizados e retificados antes do findar do século XIX, destacando a suposta supremacia do poder do Homem sobre a Natureza. Supremacia esta, que deriva da emergência da racionalidade das ciências aplicadas. A autora informa ainda que essa tendência adentra o século XX encontrando respaldo na busca pelo crescimento e desenvolvimento econômicos ${ }^{4}$, levando os sistemas fluviais a uma artificialização extrema e a consequente destruição das comunidades biológicas que compõem seus ecossistemas.

\footnotetext{
${ }^{4}$ A visão de progresso relacionada à ciência e à técnica voltará a ser mencionada nos estudos de caso, escolhidos como forma de ilustrar este contexto.
} 
A esta concepção soma-se o uso dos rios e córregos como sistema de recolhimento de esgotos, tanto industriais quanto aqueles provenientes de aglomerados humanos. As águas passam, então, de fator indispensável à vida a elemento indesejável no meio urbano. O resultado é a exclusão dos corpos hídricos das paisagens citadinas.

Esse cenário só começa a esboçar alteração na segunda metade do século XX, quando o homem se conscientiza da finitude dos recursos naturais e das consequências de uma possível escassez. Segundo Bandeira (2015), estudos começaram a rejeitar a ideia de que o homem está isento das ações da natureza, uma vez que, como organismo biológico, depende dos recursos provindos do meio ambiente e interfere diretamente na ordem ecossistêmica. Para o autor, a humanidade está propensa a consequências que não podem ser reparadas e, portanto, deve estar esclarecida das restrições a que está submetida. Nesse sentido, destaca ainda que é a natureza que oferece possibilidades para a construção de instrumentos que auxiliam o desenvolvimento e a sobrevivência humanos. Tais circunstâncias provocam mudanças e são dados importantes que podem ajudar a entender a relação do homem, as implicações sociais e os impactos na natureza.

É neste novo contexto que algumas ações começam a aparecer na tentativa de reestabelecer o equilíbrio na relação das cidades com seus rios. Essas ações, segundo Saraiva (1999) buscam considerar o potencial ecológico e a diversidade inerentes aos corpos d'água, bem como a riqueza cênica e paisagística e eles associada. De acordo com a autora, "o uso de metodologias tradicionais e tecnologias leves, ambientalmente ajustadas às especificidades físicas e culturais da região, tem vindo a ser aconseIhado, alternativamente a soluções 'duras' e artificializantes” (SARAIVA, 1999, p. 79).

Com o exposto nos itens 1 e 2, clareia-se a questão central que norteia este trabalho: "é possível reconciliar natureza e cidade através da requalificação das águas urbanas?". Assim, o objetivo deste artigo é servir de aporte inicial a esta investigação, através do estudo das primeiras iniciativas neste sentido.

\section{MATERIAIS E MÉTODOS}

Para este trabalho, realizou-se a consulta a material iconográfico e bibliográfico que discorressem sobre a relação entre rios e cidades. Partindo de um panorama inicial, procurou-se elencar casos emblemáticos de recuperação de corpos hídricos em meio 
urbano. A adoção desse método teve como objetivo estabelecer o contexto geral, propício à reflexão sobre a relação das cidades com suas águas.

Foram selecionados dois estudos de casos, brevemente abordados, de forma a estabelecer um panorama geral das intervenções envolvendo corpos hídricos: o córrego sul coreano Cheog-Gye e o córrego brasileiro Pirarungáua. O objetivo da escolha foi refletir sobre a relação das cidades com seus rios e córregos, bem como sobre o olhar que a população tem sobre os mesmos. Assim, procurou-se escolher casos bastante diversos entre si, tanto em relação aos princípios e motivos que nortearam o projeto, quanto ao tamanho e contextos urbanos em que se inserem.

Para o caso brasileiro, realizou-se também o levantamento da história do Jardim Botânico de São Paulo e do Parque Estadual das Fontes do Ipiranga consultando bibliografia referente a estudos sobre os mesmos, visita ao local para avaliação, registros fotográficos e entrevista à pesquisadora Tânia Cerati, do Instituto de Botânica.

\subsection{Estudos de caso}

\subsubsection{O Córrego Cheong-Gye ${ }^{5}$, Seul, Coréia do Sul}

A escolha deste projeto se deve ao seu contexto contemporâneo, implantado em uma "Cidade Mundial" e as implicações decorrentes de sua inserção em um mundo globalizado. Não apenas o córrego passou por requalificação, mas todo o entorno, sendo a área de intervenção vista como um "ativo paisagístico" no cento financeiro da "próspera capital do principal Tigre Asiático" (REIS; SILVA, 2016, p. 121).

Localizado ao norte do rio Han, na cidade de Seul, capital da Coréia do Sul, o córrego Cheong-Gye ${ }^{6}$ corta o centro histórico da cidade, perfazendo aproximadamente $11 \mathrm{~km}$

\footnotetext{
5 Para Reis e Silva (2016), o uso do termo "córrego Cheong-Gye Cheon" deve ser evitado, por caracterizar uma redundância. Conforme explicam os autores, a palavra cheon significa "fluxo" e, portanto, pode ser utilizada no sentido de "córrego".

6 Segundo Rowe (2013), o córrego recebeu o nome Cheong-Gyu, que significa "água limpa", durante a ocupação japonesa (1910-1945). No entanto, essa informação parece não estar correta, visto que já no final do século XIX havia a intenção de tamponá-lo, o que sinaliza as precárias condições em que o córrego já se encontrava na época.
} 
de extensão. (Figura 03) E, segundo Reis e Silva (2016), tem sido utilizado pela população local desde o século 14.

Tendo sido utilizado por mais de 600 anos como sistema de drenagem e de esgoto (REIS; SILVA, 2016), os inconvenientes causados por seus transbordamentos durante as monções aumentavam conforme a população local crescia. Em decorrência dos problemas sanitários e pela necessidade de abertura de vias, foi elaborado um plano de tamponamento do córrego para a construção de viário em 1895 e que saiu do papel apenas após a ocupação japonesa (1910-1945). No entanto, as obras são interrompidas diversas vezes em decorrência das sucessivas guerras que se abateram sobre o país na primeira metade do século XX até o seu completo abandono (REIS; SILVA, 2016). Em um contexto de pobreza e miséria, fruto dos conflitos mencionados, as margens do Cheong-Gye são ocupadas por barracos precários sobre palafitas (Figuras 04 a 07).

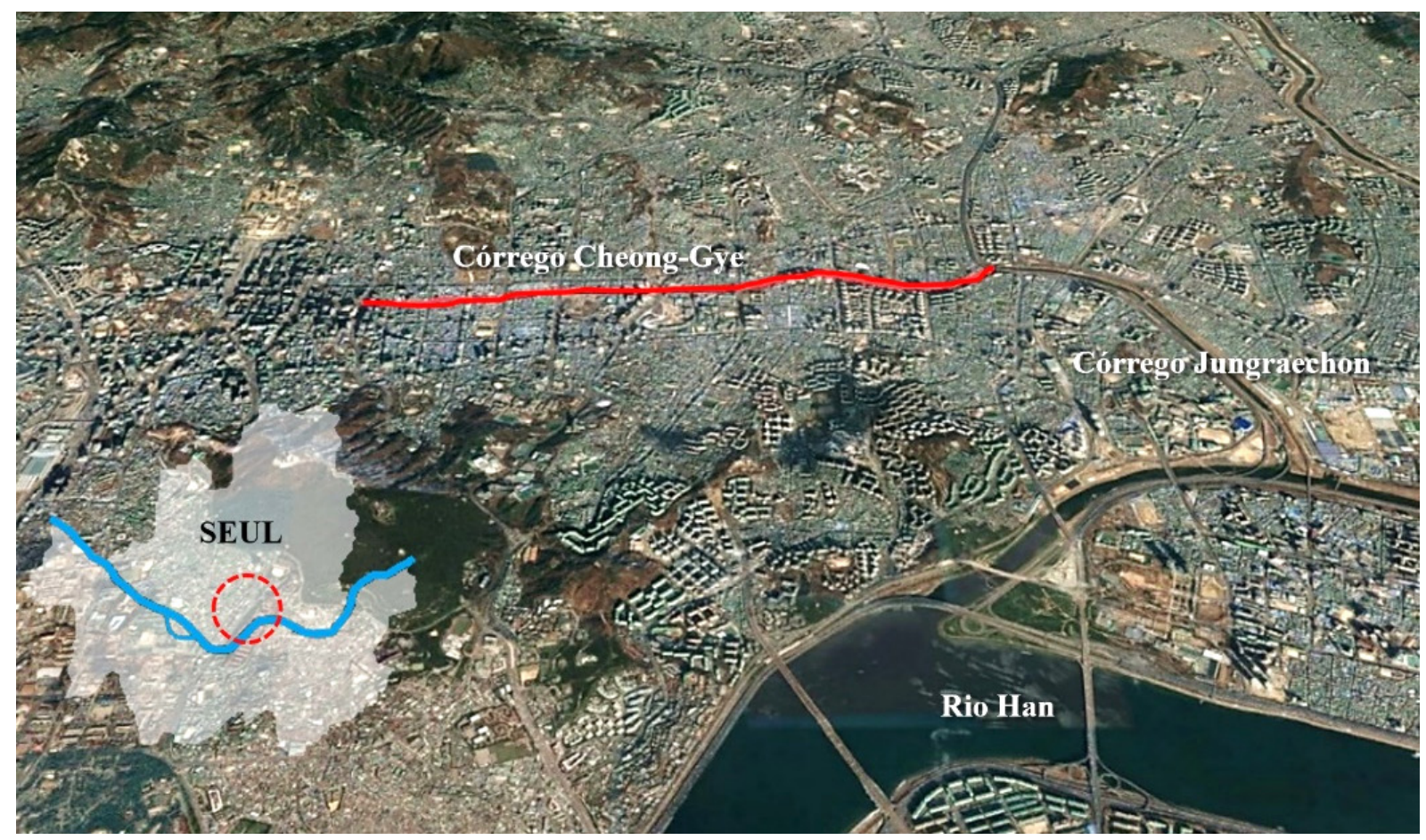

FIGURA 03. Localização do córrego Cheong-Gye. Fonte: Imagem Google Earth editada pelas autoras

Esse cenário muda na década de 1960. Contando com auxílio externo, a República da Coréia passa a exibir uma notável taxa de crescimento do PIB - Produto Interno Bruto - e com ela, novas necessidades comerciais, administrativas, financeiras e espaciais surgem. Segundo Reis e Silva (2016), é nesse período, conhecido como "Milagre do Rio Han", que são retomados os trabalhos de cobertura do córrego Cheong-Gye. 
Nesse sentido, é possível afirmar que o córrego foi expropriado para possibilitar o salto em direção à modernidade, à era do concreto armado e do automóvel, materializada através da implementação de grandes eixos viários (ROWE, 2013). Essa concepção de progresso tem seu ápice com a construção de uma estrutura colossal sobre o leito carroçável que tamponava o córrego: a Cheong-Gye Expressway, uma via expressa elevada de $16 \mathrm{~m}$ de largura e que se destinava a conectar o centro aos bairros adjacentes. No entanto, tal estrutura caracterizou-se como uma barreira urbana causando, de acordo com Reis e Silva (2016), um impacto paisagístico negativo no entorno e "provocando uma mancha de obsolescência e degradação ao seu redor" (REIS: SILVA, 2016, p. 119). ${ }^{7}$

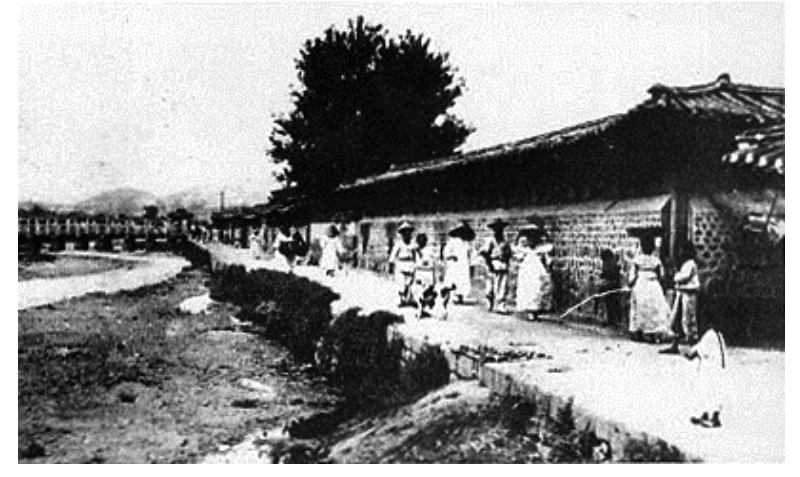

FIGURA 04. Córrego Cheong-Gye por volta de 1890. Fonte: Seoul Metropolitan Government (2009a).

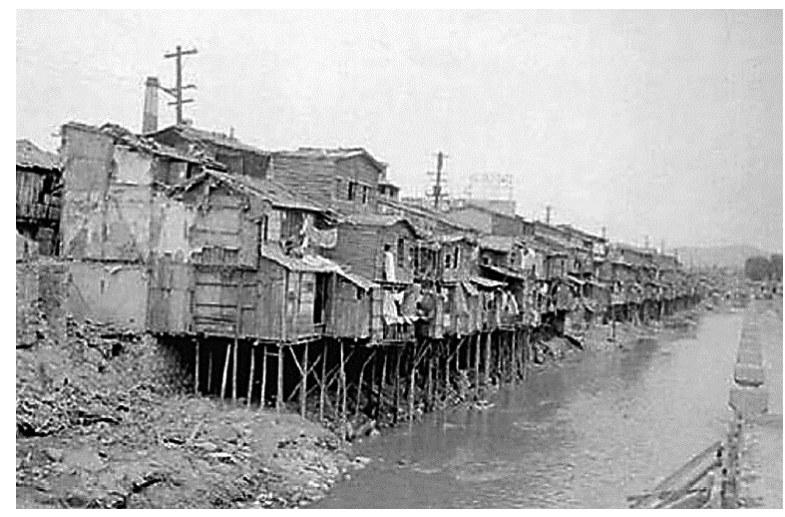

FIGURA 06. O córrego margeado por barracos em palafitas em 1950. Fonte: Reis e Silva (2016)

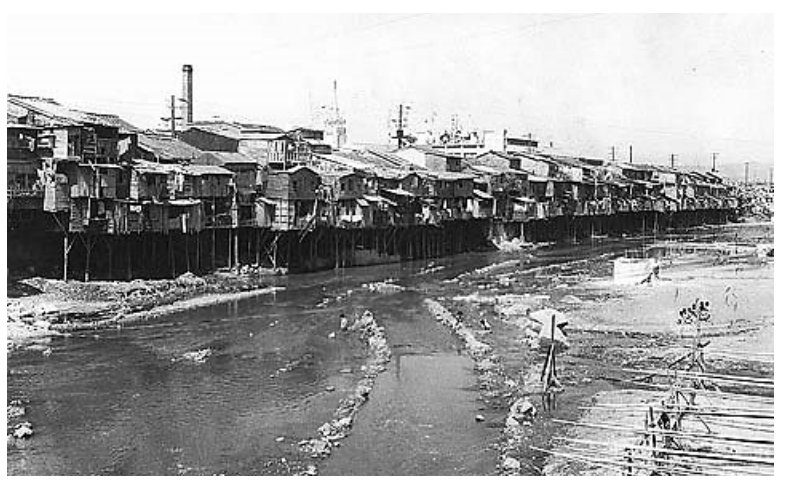

FIGURA 05. Barracos do período colonial japonês. Fonte: Namu Moe (s/d).

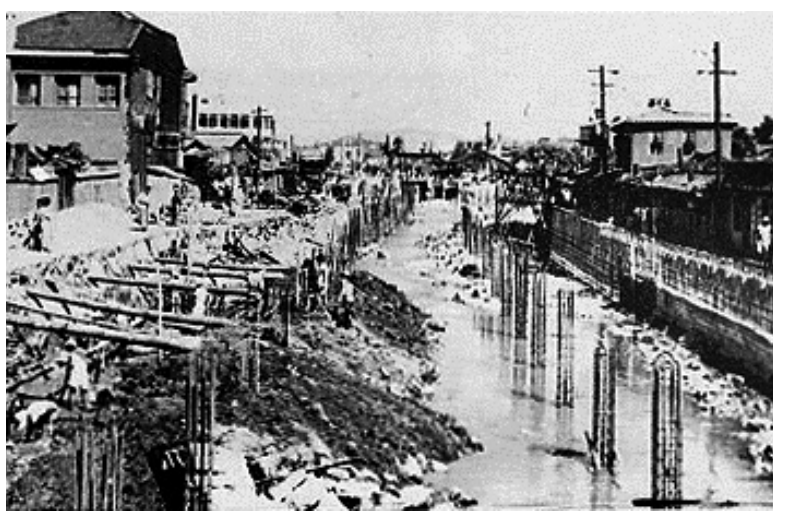

FIGURA 07. Tamponamento do córrego na década de 1950. Fonte: Seoul Metropolitan Government (2009b).

\footnotetext{
7 Reis e Silva (2016) pontuam ainda que a deterioração do entorno do córrego Cheong-Gye se insere no processo de declínio dos centros históricos das grandes cidades do mundo capitalista e que está relacionado com o desenvolvimento de novas centralidades. Este assunto não será abordado neste trabalho, bem como a questão da gentrificação decorrente do processo de requalificação da área (que não pode ser tomada pelo referencial latino-americano).
} 
Com a virada do milênio, o córrego Cheong-Gye e seu entorno passam por mais uma transformação radical. Lee Myum-Bak, prefeito de Seul entre os anos 2002-2006 e que aspirava projetar-se nacionalmente através de um feito memorável, encontrou respaldo na proposta de criação de uma nova política urbana, avessa ao "rodoviarismo" e que devolvesse a escala humana da cidade à população. Assim, "para fazer jus às necessidades simbólicas da nova "cidade mundial'" (REIS; SILVA, 2016, p. 123), a reforma abrangeu o destamponamento do córrego, despoluição de suas águas e renovação de parte da área central, incluindo sistema de esgoto, viário e iluminação. Seul ganha, então, o status de cidade amiga das pessoas e do meio ambiente e Lee Myum-Bak se elege presidente (REIS; SILVA, 2016, ROWE, 2013).

Após um período de pouco mais de três anos de obras, de 2003 a 2005, o córrego foi descoberto e restaurado, recebendo orla, ruas de pedestres ao longo de suas margens, além de áreas para o transbordo das cheias decorrentes das monções (Figura 08). 0 projeto propiciou à cidade quase $6 \mathrm{~km}$ lineares de áreas verdes e fez ressurgir as águas do Cheong-Gye que estavam esquecidas há quarenta anos.
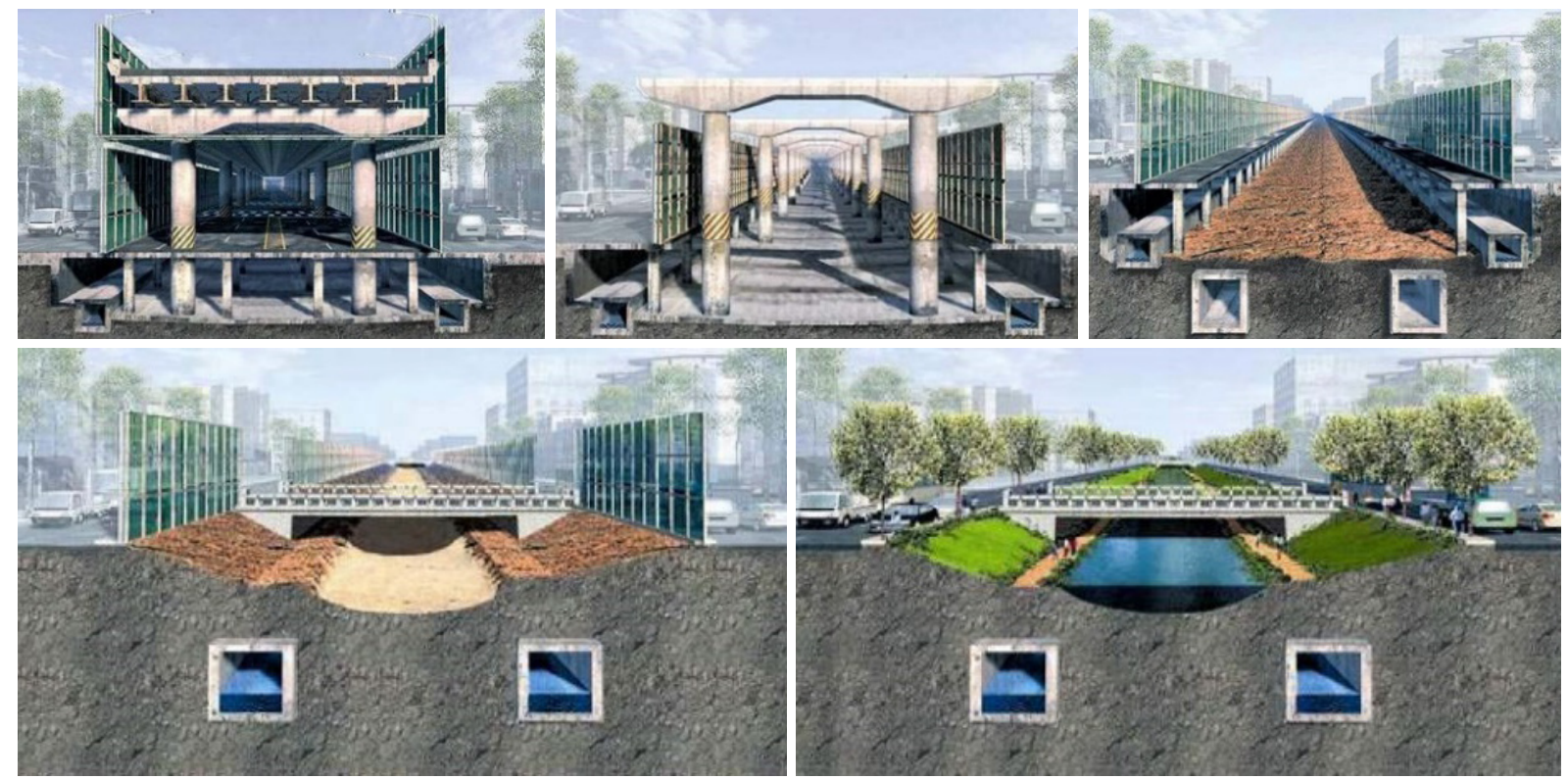

FIGURA 08. Etapas de destamponamento do córrego Cheong-Gye. Fonte: LEE, In-Keum (2006)

Apesar da fama, que rompeu fronteiras, e de ser considerado um modelo de requalificação de corpos hídricos em meios urbanos, o córrego é, na verdade, um curso de água artificial. Por ser intermitente e por ter perdido a maioria de seus afluentes em decorrência da urbanização, o Cheong-Gye recebe água bombeada do rio Han, criando um fluxo contínuo com $40 \mathrm{~cm}$ de largura durante a maior parte do ano. 
Ressalvas à parte, houveram muitos ganhos com a iniciativa, principalmente em relação à mobilidade urbana ${ }^{8}$ e ao lazer da população (Figuras 09 a 12). Quanto à qualidade ambiental, é possível constatar uma sensível melhora na qualidade do ar em decorrência da diminuição do número de automóveis circulando na região. E com o retorno da vegetação ao longo do curso do córrego é possível perceber uma redução do efeito de ilha de calor na área do projeto, que não mais possui asfalto irradiando calor, além do incremento da biodiversidade, com o retorno de aves, peixes e insetos.

Conclui-se, então, que a requalificação do córrego Cheong-Gye tem valor por possibilitar algumas discussões, mesmo que fora das contestações socialmente organizadas, como a primazia do automóvel particular, o impacto de grandes obras de infraestrutura, a qualidade dos rios e córregos urbanos, entre outras.
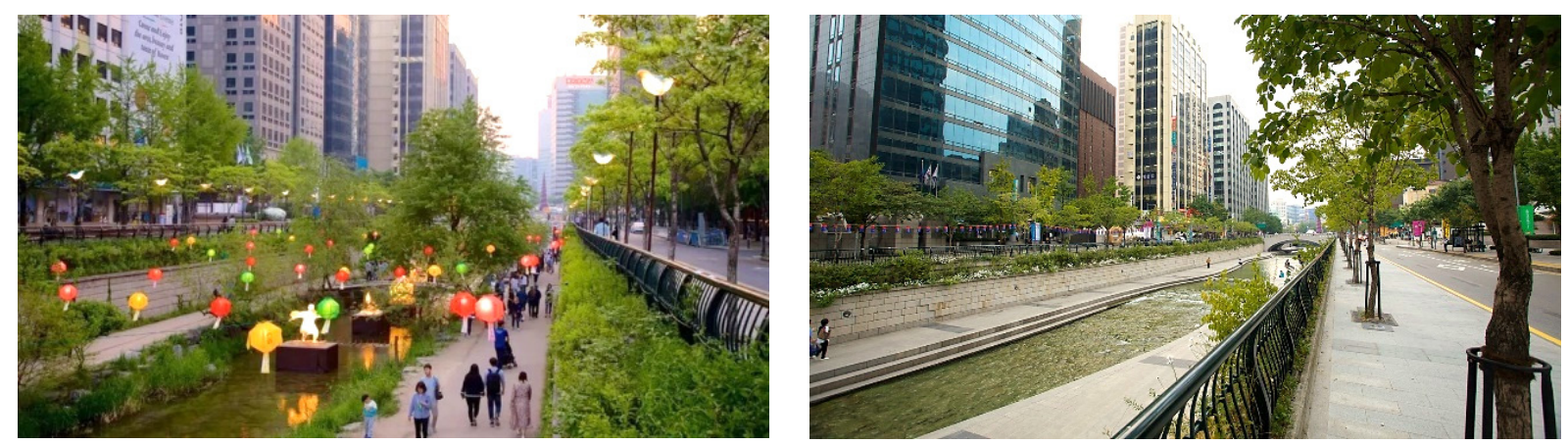

FIGURAS 09 e 10. Córrego Cheong-Gye na atualidade. Fonte: Expedia (s/d).
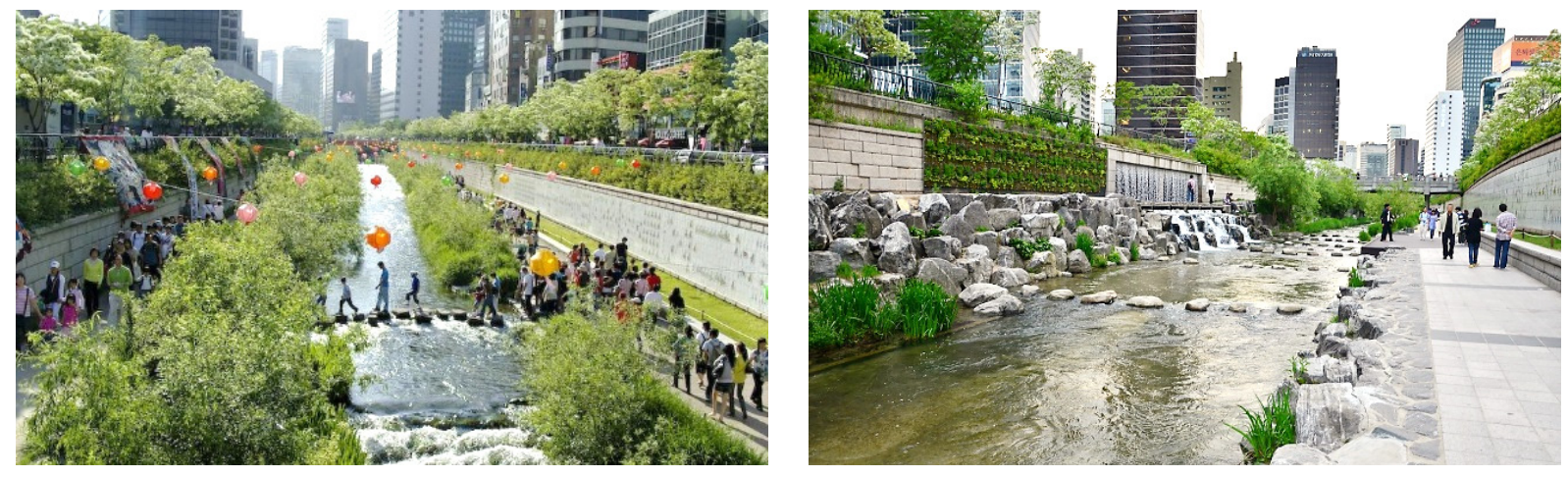

FIGURAS 11 e 12. Córrego na atualidade. Fontes: Gaete (2014) e Simatupang (2018), respectivamente.

\footnotetext{
${ }^{8}$ De acordo com Reis e Silva (2016) e Rowe (2013), ao contrário do temido colapso do sistema viário, a demolição da via expressa provocou uma reorientação nos usos tanto do transporte público quanto do individual, contribuindo para a diminuição do volume de tráfego.
} 


\subsubsection{O córrego Pirarungáua, São Paulo, Brasil}

Um exemplo da mudança de paradigma na relação entre rios e cidades brasileiras pode ser encontrado no município de São Paulo: o córrego Pirarungáua. Esse córrego é um dos formadores do Riacho do Ipiranga e sua nascente encontra-se dentro dos limites do Jardim Botânico, uma das instituições que compõe o Parque Estadual das Fontes do Ipiranga, popularmente conhecido como Parque do Estado. (Figuras 13, 14 e 17) Tamponado na década de 1940 para dar lugar a uma alameda, o córrego permaneceu excluído da paisagem por mais de 60 anos, voltando a ressurgir apenas em 2008.

Para que se possa entender melhor essa trajetória, é necessário citar brevemente a história do Jardim Botânico de São Paulo e do parque que o abriga, o PEFI - Parque Estadual das Fontes do Ipiranga.

Localizado na região sudeste do Município de São Paulo, a uma altitude de cerca de 800 m, o PEFI - Parque Estadual das Fontes do Ipiranga - possui uma área de aproximadamente 540 ha e apresenta vegetação característica de floresta ombrófila densa de encosta atlântica ${ }^{9}$. O parque também abriga as nascentes do histórico Riacho do Ipiranga e o maior fragmento de Mata Atlântica inserido na área urbana da RMSP - Região Metropolitana de São Paulo - cumprindo um importante papel no equilíbrio climático e na qualidade do ar das áreas vizinhas urbanizadas (Figuras 13 e 14).

${ }^{9}$ Cf. Plano de Manejo. Resumo executivo. Elaborado pelo Instituto de Botânica em junho de 2007. Segundo o Manual Técnico da Vegetação Brasileira, editado pelo IBGE em 2012, a designação Floresta Ombrófila Densa ou Floresta Tropica Fluvial é concedida a fisionomias ecológicas que ocorrem tanto na Amazônia como nas áreas costeiras e que correspondem a um tipo de vegetação perenifólia caracterizada pela presença de fanerófitos ${ }^{(1)}$, lianas $^{(2)}$ e epífitas ${ }^{(3)} \mathrm{em}$ abundância. Esta formação está condicionada a ocorrência de temperaturas elevadas e altas precipitações, bem distribuídas durante o ano, o que determina uma situação bioecológica onde praticamente não ocorrem períodos de seca.

(1) plantas cujas gemas de renovação se encontram a mais de $25 \mathrm{~cm}$ do solo.

(2) plantas trepadeiras lenhosas que iniciam seu desenvolvimento no solo e com o crescimento perdem sua habilidade de se sustentar, necessitando de suporte para ascender à copa.

(3) plantas que crescem sobre a superfície de outra sem Ihe causar prejuízo, como por exemplo, bromélias e orquídeas. 


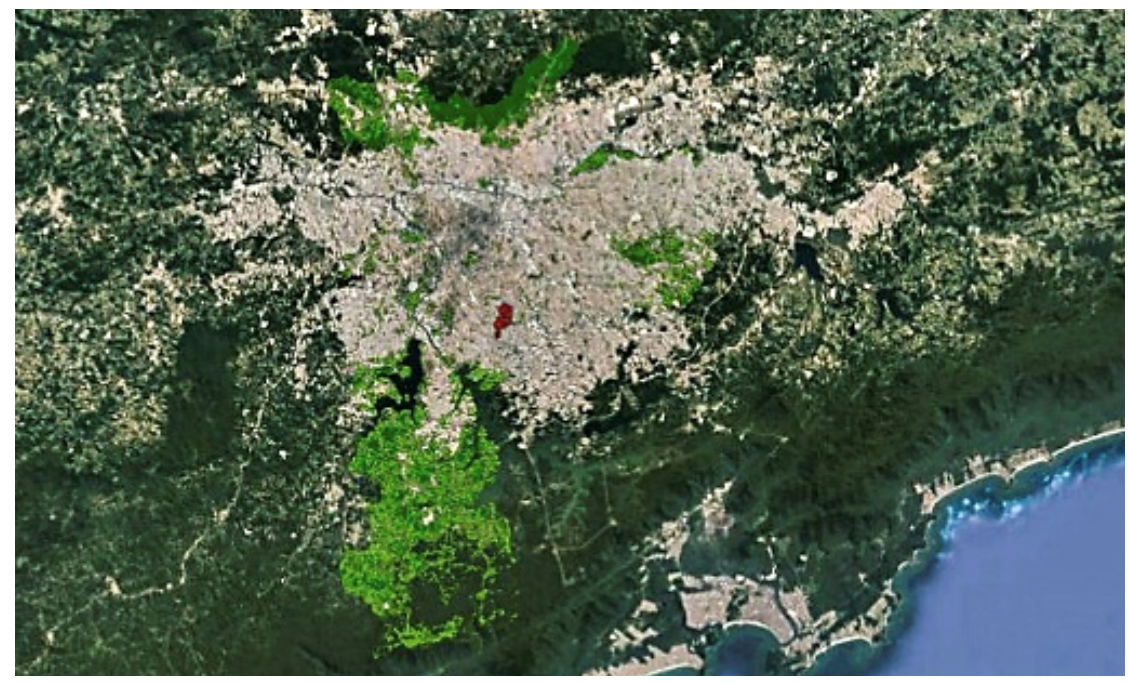

FIGURA 13. RMSP com a localização dos fragmentos de Mata Atlântica (verde claro) e do PEFI (vermelho). É possível verificar que o mesmo está encravado em meio a malha urbana. Fonte: Elaborado pelas autoras no Google Earth Pro a partir de arquivos disponibilizados no Portal GeoSampa.

Pertencente ao Estado desde $1893^{10}$, quando as primeiras desapropriações foram realizadas, sua criação está ligada aos movimentos conservacionistas que floresciam na época (hipótese levantada por BANDEIRA, 2015)11. Apesar do processo de

${ }^{10}$ A Repartição de Águas do Estado iniciou a desapropriação de matas e pequenas chácaras situadas na área onde atualmente está implantado o Parque que abriga o Jardim Botânico de São Paulo a partir da promulgação do Decreto Estadual no 204 de 12 de setembro de 1893 que declarou de utilidade pública os terrenos da Bacia do Riacho Ipiranga. No entanto, apenas em 1917 a região passou a ser integralmente propriedade do Governo do Estado e a denominar-se Parque do Estado.

11 Bandeira (2015) destaca, apoiada no trabalho de Franco e Drummond (2004) e de Diegues (2001), duas visões predominantes no cenário internacional e que influenciaram outros países, inclusive o Brasil. A primeira, de concepção preservacionista, se caracteriza por reverenciar esteticamente e espiritualmente a natureza. Nomes como John Muir, Henry David Thoreau e Aldo Leopold se destacam dentro dessa linha de pensamento. Já a segunda, de concepção conservacionista, orienta que o uso dos recursos naturais seja feito de forma cautelosa, racional. Essa intepretação tem como base o pensamento de Gifford Pinchot e pode ser considerada o prenúncio do que atualmente se entende por desenvolvimento sustentável. Dentro deste panorama, a autora destaca três grupos pioneiros que teriam contribuído com o pensamento conservacionista no Brasil e entre seus expoentes cita Edmundo Navarro de Andrade, Alberto Lofgren, Hermann von Ihering, Alberto Torres, Alberto José Sampaio, Armando Magalhães Corrêa, Cândido de Melo Leitão e Frederico Carlos Hoehne. Bandeira intenciona, com isso, chamar a atenção para o fato de que as preocupações ambientais já estavam presentes no Brasil em períodos anteriores aos trabalhos tidos como precursores internacionais dessa discussão (como o trabalho de Rachel Carson, Silent Spring, de 1962 ou a Conferência de Estocolmo, ocorrida em 1972). A autora ainda justifica o cenário propício para a criação do Parque do Estado, uma vez que o cuidado com as áreas verdes não fazia parte do pensamento predominante da época, sublinhando o contexto político e intelectual no qual ele se insere, ou seja, um ambiente marcado pela crença de que o país solucionaria seus problemas através do pensamento científico. Isso posto, faz-se necessário destacar que a preocupação ambiental aqui tratada se reveste de características tanto cientificistas quanto simbólicas, bastante diferente do contexto atual. Para uma síntese da evolução da conservação ambiental, no Brasil e no exterior, ver Franco (2001). 
retirada da comunidade ter se iniciado "para deixar que as florestas neles se refizessem e tudo voltasse às condições primitivas no menor prazo de tempo possível e tanto quanto isso é admissível na natureza" (HOEHNE; KUHLMANN; HANDRO, 1941, apud BANDEIRA, 2015, p. 115), o objetivo inicial de preservação da área estava ligado à visão utilitarista de captação de água, uma vez que os mananciais aí existentes eram os responsáveis pelo abastecimento da região sudeste da capital. Essa visão permaneceu até $1928^{12}$, quando a captação é encerrada em virtude da poluição e do baixo volume que os mananciais atingiram (BANDEIRA, 2015; ROCHA, CAVALHEIRO, 2001). Nesta mesma época, o naturalista Frederico Carlos Hoehne ${ }^{13}$ é convidado para chefiar a Seção de Botânica, recém transferida do Museu Paulista (também conhecido como Museu do Ipiranga) e responsável por cuidar de cerca de 220 ha da área total (ROCHA; CAVALHEIRO, 2001). O plano de urbanização da área estabeleceu a abertura das vias internas e de algumas "atrações", sendo uma delas o orquidário, embrião do JB - Jardim Botânico. As obras para a implantação do JB foram executadas lentamente a partir de 1930, entre elas: abertura da Alameda Fernando Costa, drenagem de terrenos, construção de novo portão e de casas da administração e da guarda, laboratórios, abertura de caminhos e aquisição de novas coleções (HOEHNE et al. 1941, apud ROCHA; CAVALHEIRO, 2001). Entretanto, somente em 1938 o JB é fundado oficialmente, junto com a criação do Departamento de Botânica, órgão responsável por sua administração e que passou a ser denominado Instituto de Botânica em 1942. ${ }^{14}$

${ }^{12}$ Cf. http://jardimbotanico.sp.gov.br/o-jardim/historico-do-jardim-botanico/

${ }^{13}$ Brasileiro, descendente de alemães, nascido no ano de 1882 na cidade de Juiz de Fora, Minas Gerais, tido como autodidata, Frederico Carlos Hoehne participou de 15 expedições científicas pelo Brasil e alguns países limítrofes entre 1908 e 1948, tendo produzido um vasto conhecimento científico a respeito da flora brasileira e se consolidado como cientista de campo. De acordo com Bandeira (2015), Hoehne é herdeiro dos viajantes naturalistas, sendo considerado um dos pioneiros na ideia de conservação no Brasil.

14 Um breve histórico sobre a formação do Jardim Botânico de São Paulo, partindo das primeiras tentativas de instalação de Jardins Botânicos no Brasil, pode ser conferido em Rocha e Cavalheiro (2001). 


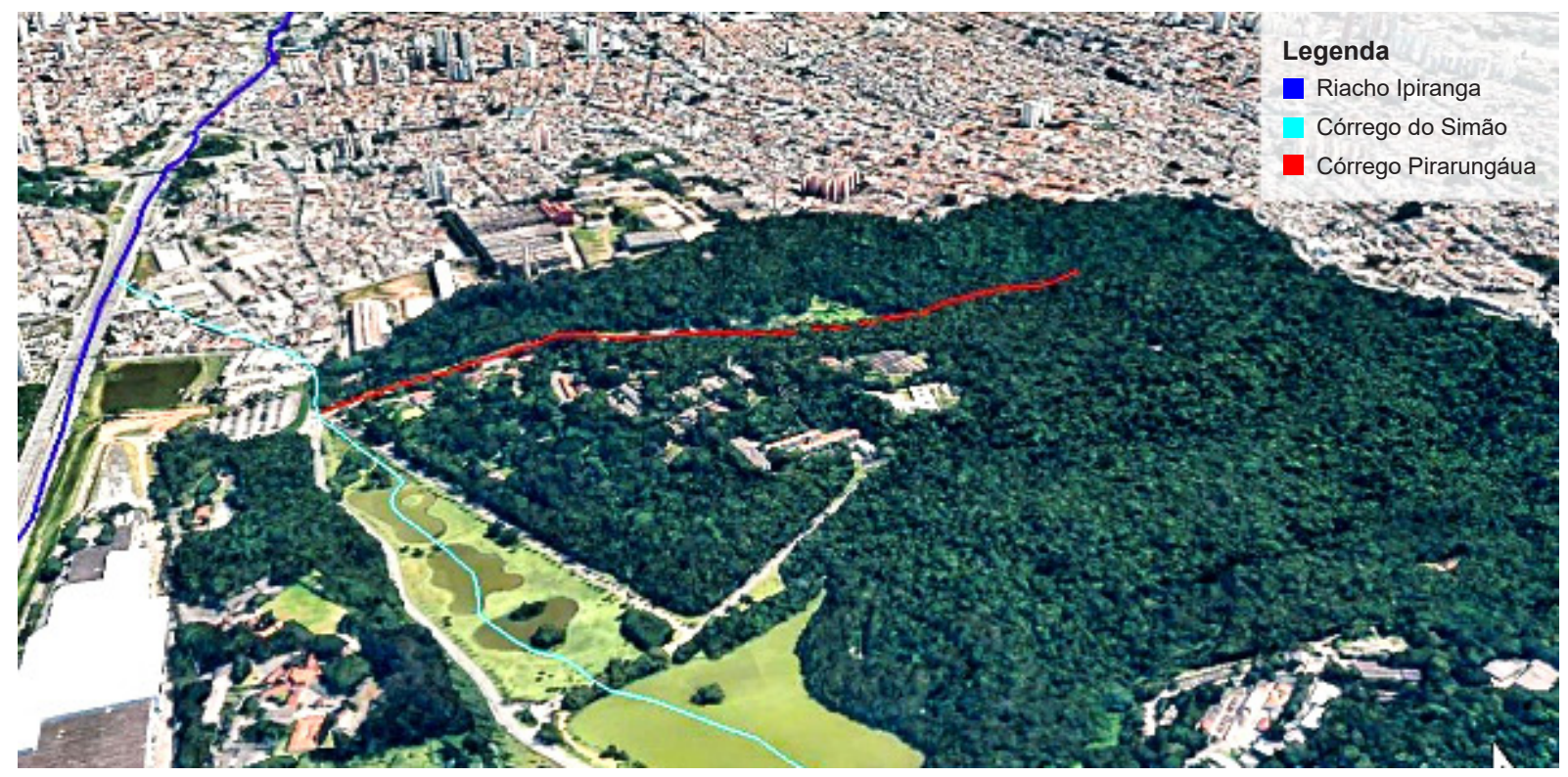

FIGURA 14. Vista aérea parcial norte do PEFI, região do Jardim Botânico, e entorno densamente urbanizado. Fonte: Elaborado pelas autoras a partir de imagem extraída do Google Earth

Logo após, em 1945, concluiu-se a retificação e canalização do córrego Pirarungáua. A galeria que passou a abrigá-lo foi construída com a intenção de se obter uma área plana, que destacasse as edificações e onde pudesse ser implantada uma alameda margeadas de palmeiras brasileiras: a Alameda Fernando Costa, com suas fileiras de jerivás e jussaras. (HOEHNE, 1942, 1944, 1946 e 1949a apud ROCHA; CAVALHEIRO, 2000) (Figura 15). Sobre a escolha das espécies de palmeiras, Bandeira (2015) revela que a intenção de Frederico Carlos Hoehne era ressaltar a flora nativa, refletindo o ideal nacionalista do botânico ${ }^{15}$.

É interessante notar que, apesar de todo o discurso em prol da preservação dos recursos naturais, o córrego Pirarungáua foi tamponado na década de 1940, época em que o Jardim Botânico estava sob a chefia do naturalista Frederico Carlos Hoehne. Assim, é necessário considerar o contexto cultural em que o JB foi criado e a postura de seu idealizador frente a este contexto.

15 O caráter nacionalista dos pensamentos de Hoehne pode ser constatado no seguinte trecho: No Brasil não são de hoje os protestos e clamores contra a devastação da natureza - quinhão unico de que nos podemos realmente ufanar e orgulhar deante dos demais povos, - não é, tão pouco, de nossos dias a lembrança da urgente necessidade de hortos e estações biologicas bem como reservas florestaes publicas (HOEHNE, 1925, apud BANDEIRA, 2015, p.129 - grifo nosso). 


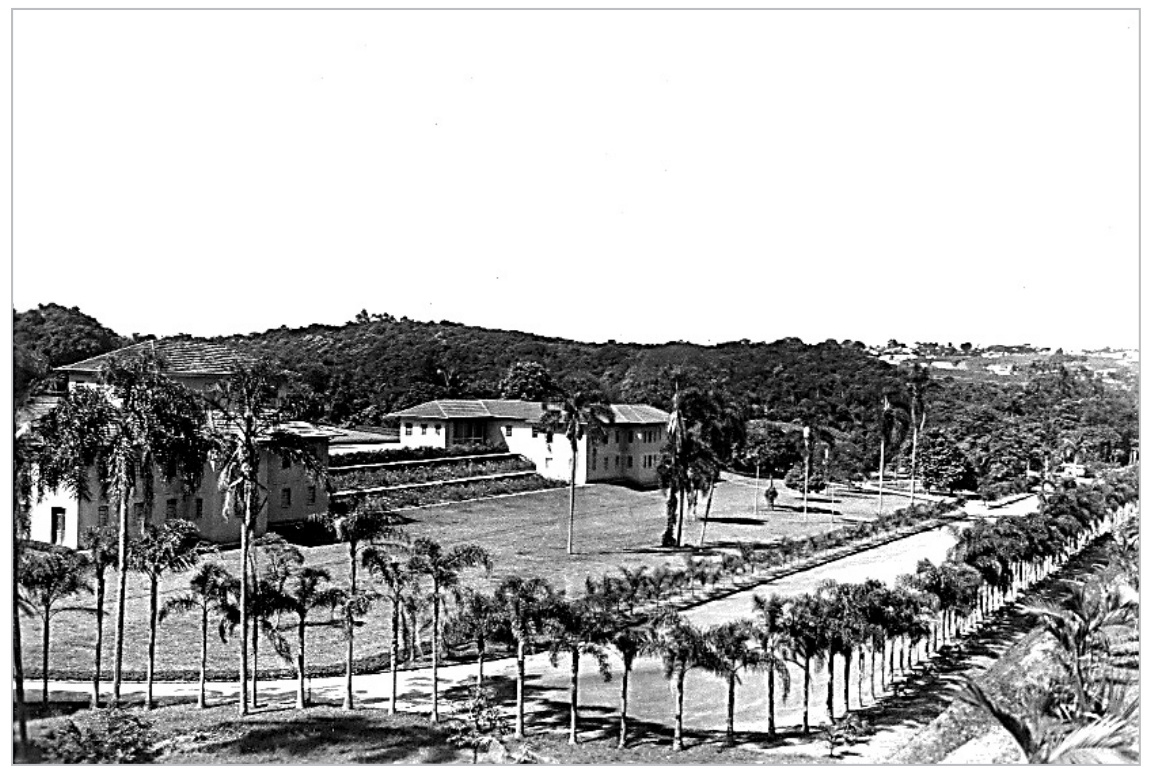

FIGURA 15. Vista da Alameda Fernando Costa na década de 40. O córrego Pirarungáua já se encontra sob o calçamento. Fonte: Acervo do Instituto de Botânica.

Entre os anos 1889 e 1930 o Brasil passa por um período de urbanização e industrialização, onde a ciência era vista como uma forma para se alcançar a modernidade e deixar para trás o período colonial. E em São Paulo, as riquezas advindas do café ofereciam o aporte econômico necessário a estes ideais. Diante desse quadro, os rios passam a ser considerados "obstáculos" ao progresso e a evidência desse pensamento pode ser notada nas grandes transformações hidrográficas sofrida pela cidade de São Paulo entre os séculos XIX e XX.

A capital paulista estava imersa sob um contexto em que parecia necessário inseri-la sob os marcos da cidade que deveria ser limpa, tanto em função da necessidade de higiene inerente ao processo de adensamento populacional quanto ao fato de as elites instaladas no poder almejarem colocá-la entre àquelas que estavam sob os fundamentos modernizadores e civilizatórios inerentes ao sistema capitalista, exemplificadas principalmente por Paris e Londres. (SANTOS, 2006, apud BANDEIRA, 2015, p. 89).

Essa concepção, de caráter higienista, se fortaleceu com o crescimento populacional, que aumentou não apenas a demanda por água potável, mas também a produção de dejetos - que sem destinação adequada, acabavam sendo despejados nos rios e córregos da cidade. Essa situação colaborou para a desvalorização de rios e várzeas dando início ao processo que gradativamente alteraria as paisagens hídricas das áreas urbanizadas (canalização dos cursos d'água, ocupação das várzeas, construção de vias marginais, entre outros). 
Assim, é preciso se atentar para o fato de que a relação cidade-natureza na virada dos séculos XIX e XX é construída sob forte influência de fatores sociais, econômicos e políticos. E para que se possa compreender a posição de Hoehne - chefe do Instituto de Botânica na época de tamponamento do córrego Pirarungáua - é necessário situálo neste "contexto político e intelectual, marcado por ideias que buscavam a construção de um Estado forte e de uma identidade nacional" (BANDEIRA, 2015, p.129) e pela visão dos corpos d'água como obstáculos ao alcance destes ideais.

A primeira grande reforma da Alameda Fernando Costa que se tem registro ocorreu na década de 1990, época em que recebeu piso em mosaico português e a instalação de bancos sob pérgolas metálicas (Figura 16). Os projetos necessários foram feitos pelo Departamento de Projetos da Paisagem e contemplavam a reforma da alameda e da portaria principal (ROCHA; CAVALHEIRO, 2000). Não consta, na bibliografia consultada, registros da intenção de destamponar o córrego nessa época, mesmo com a difícil manutenção do piso e dos vários afundamentos ocorridos desde então.

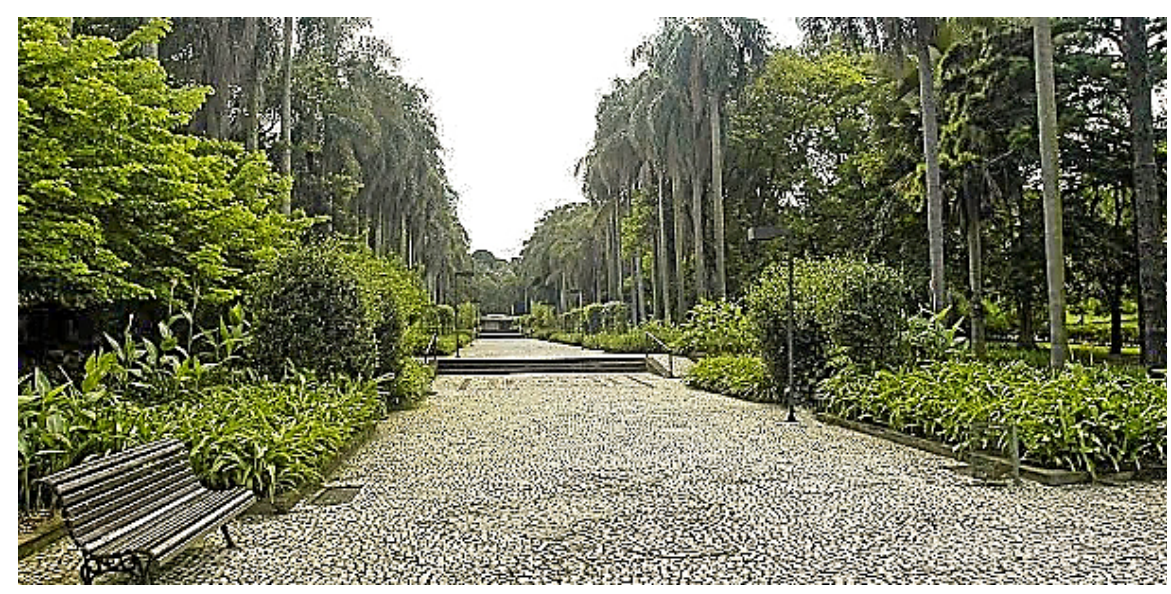

FIGURA 16. Vista da Alameda Fernando Costa antes do ressurgimento do córrego Pirarungáua. Fonte: Ramalhoso (2016)

O córrego Pirarungáua nasce dentro dos limites do Jardim Botânico de São Paulo e, por consequência, tem a qualidade de suas águas preservada até a sua foz, o córrego do Simão (Figura 17). Apesar de não apresentar um dos principais fatores de exclusão dos corpos hídricos das cidades, a poluição por esgoto, o córrego foi tamponado e, como visto anteriormente, assim permaneceu por muitos anos. 


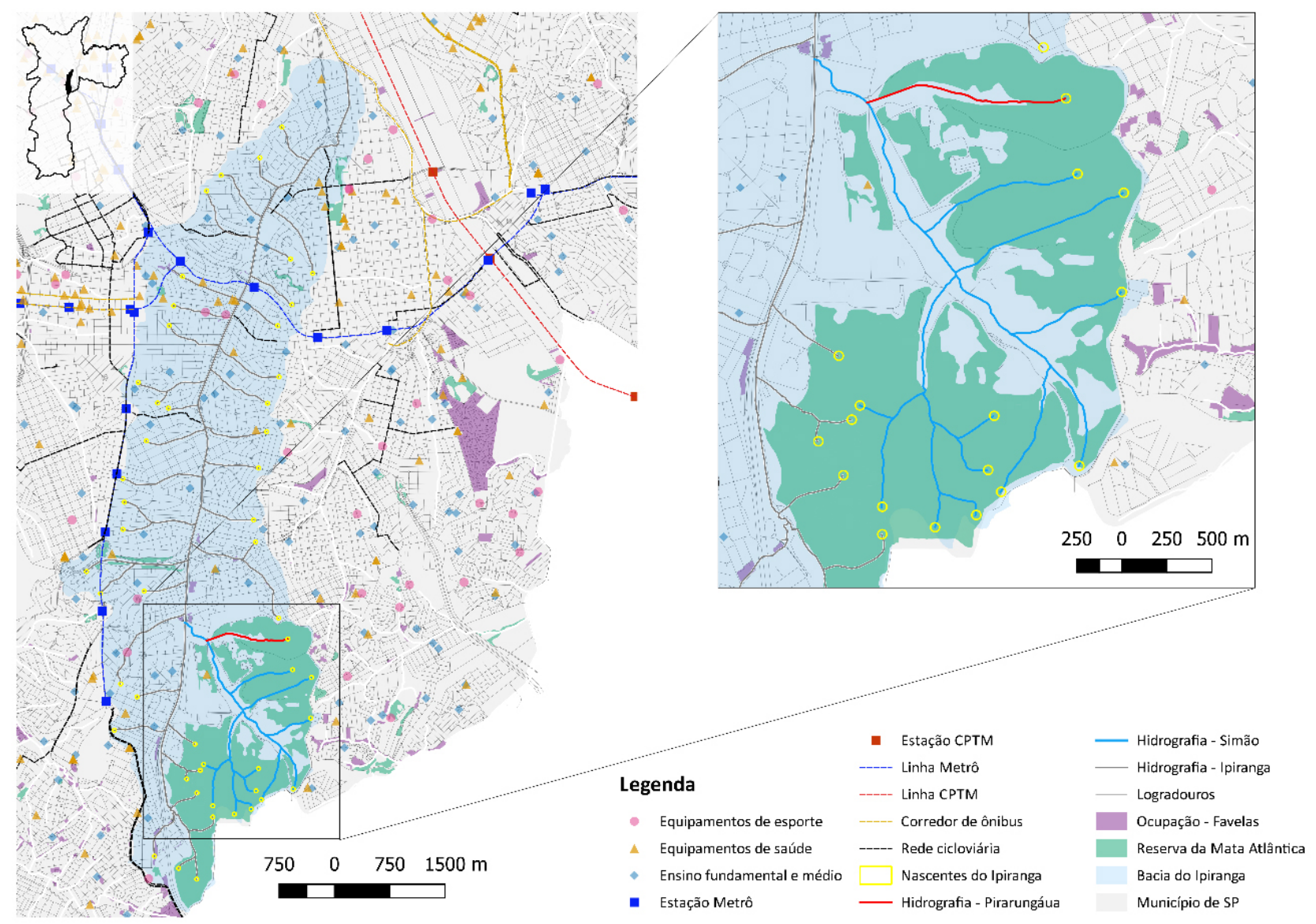

FIGURA 17. Bacia do riacho Ipiranga com a localização dos córregos do Simão e Pirarungáua. A grande área em verde, Reserva da Mata Atlântica, é correspondente à mata existente no PEFI. Fonte: Elaborado pelas autoras a partir de arquivos disponibilizados no Portal GeoSampa.

No entanto, entre 2007 e 2008 ocorreu uma grande intervenção em um trecho do córrego que estava tamponado, contando inclusive com a relocação de algumas palmeiras da Alameda Fernando Costa e a demolição de uma edificação administrativa conhecida como "redondo" (Figuras 18 a 21). Segundo Tânia Cerati, integrante do Núcleo de Pesquisa em Educação do Instituto de Botânica, a manilha de canalização cedeu e na sondagem verificou-se que havia a necessidade de trocar toda estrutu$\mathrm{ra}^{16}$. Entre executar a reforma necessária ou retirar a galeria existente, optou-se pela segunda e, assim, fazer com que o córrego ressurgisse. O que iria ao encontro dos propósitos do JB, de acordo com a pesquisadora.

${ }^{16}$ Dados obtidos em entrevista concedida pela pesquisadora durante a visita ao JB em 22 de maio de 2018. 
O projeto de requalificação da área ficou sob os cuidados do arquiteto José Paulo Ganzelli, também autor do projeto da Trilha da Nascente, executado em 2005. Com o calçamento existente retirado, Ganzelli propôs a instalação de decks de madeira suspensos para que os visitantes pudessem observar o córrego correndo a céu aberto e a mata ciliar que acompanha suas margens. Segundo Cerati, o espaço foi pensado para a educação ambiental, uma vez que possibilita o entendimento da importância e dependência entre mata ciliar e corpos d'água ${ }^{17}$. A pesquisadora ainda informou que a requalificação da alameda abrangeu a regeneração das margens do córrego através do plantio de exemplares da Mata Atlântica oriundos das obras do Rodoanel - trecho sul. Através de um convênio com a Dersa, depositária das plantas remanescentes da obra, o JB coletou sementes, plantas herbáceas e trepadeiras, possibilitando a execução da proposta.
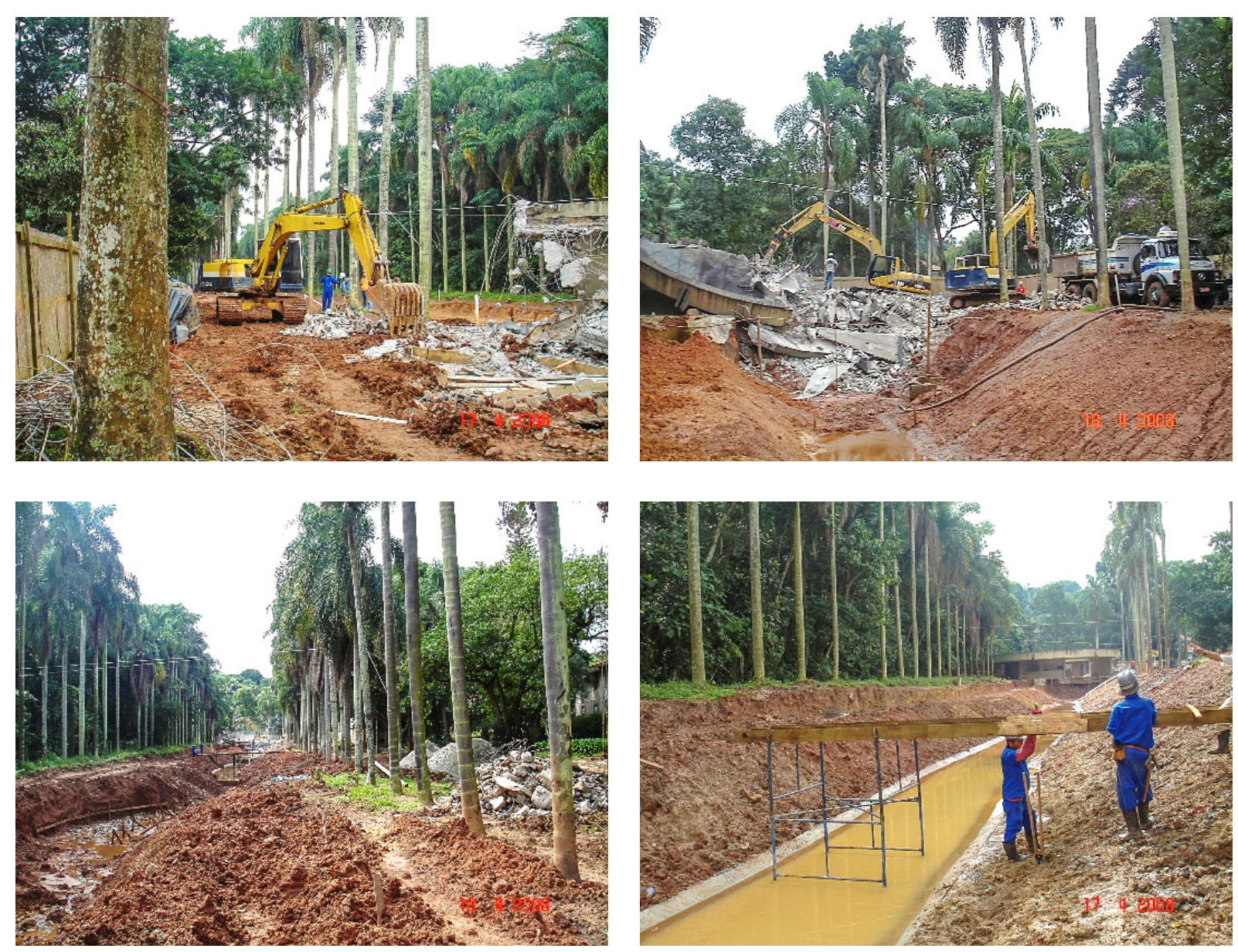

FIGURAS 18 a 21. Obras para retirada do calçamento da Alameda Fernando Costa e destamponamento do córrego Pirarungáua. Fonte: Acervo do Instituto de Botânica.

17 supra 
A presença marcante das palmeiras jerivás, plantadas na década de 1940, preserva o caráter monumental do eixo original, principalmente a partir da entrada do parque. Mas há, sem dúvida, a construção de um novo olhar ao longo do percurso proposto. $O$ espaço agora é mais convidativo, no lugar do mosaico português irradiando calor temse um microclima agradável, onde a paisagem não pode ser apreendida de imediato. É necessário tempo para a descoberta (Figuras 23 a 28).

"O espaço se tornou mais agradável para ser visitado, as pessoas param para observar o córrego e a mata. O projeto proporcionou que as pessoas ficassem mais próximas do ambiente natural." (Tânia Cerati, pesquisadora do Instituto de Botânica, em entrevista concedida em 22 de maio de 2018).
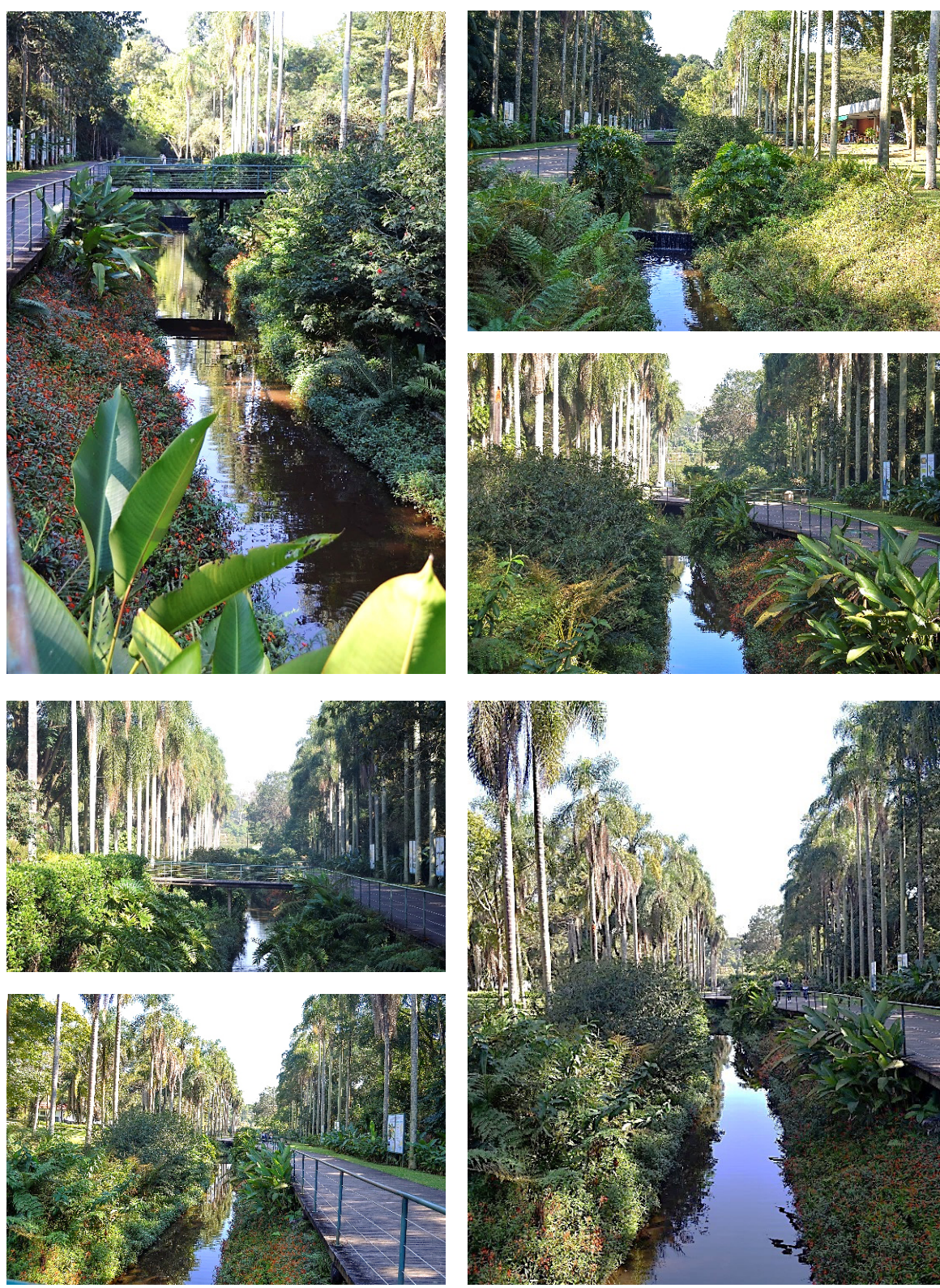

FIGURAS 23 a 28 . Alameda Fernando Costa nos dias atuais com o córrego Pirarungáua correndo a céu aberto. Fonte: Fotos autorais, tiradas em 22 de maio de 2018. 
Nesse sentido, a iniciativa pode ser considerada um caso bem-sucedido pela construção de uma paisagem que chama a atenção por sua beleza e riqueza vegetal, contribuindo para a aproximação da população com as águas urbanas. E mesmo tendo sido implantada em um pequeno trecho da extensão do córrego (cerca de $240 \mathrm{~m}$ ), caracteriza-se como um exemplo de infraestrutura verde a ser replicado.

O sucesso do projeto pode ser constatado pelo aumento na visitação e pela repercussão na mídia na época de sua inauguração. O projeto é, sem dúvida, significativo, o Jardim Botânico que já era um verdadeiro oásis em meio à loucura da cidade de São Paulo, cercado por vegetação, ganhou um novo atrativo. Porém, é necessário analisar essa mudança de postura em relação aos corpos d'água um pouco mais a fundo.

Se tanto as canalizações convencionais dos cursos d'água quanto a construção de piscinões ainda figuram como necessidade diante das frequentes inundações que assolam as áreas urbanas de muitas cidades, demonstrando que os aspectos ambientais ainda não são privilegiados quando comparados aos aspectos econômicos, as transformações do Pirarungáua aqui relatadas não podem ser atribuídas somente à demanda por reestruturação do local, uma vez que a galeria por onde o córrego passava poderia ter sido refeita e o Pirarungáua, continuado no esquecimento.

\section{CONCLUSÃO}

A partir do exposto, é possível afirmar que a descanalização de córregos está ligada ao contexto ambiental que emerge no século XXI, onde a visão ingênua da experiência humana, abdicada das influências ambientais, não mais encontra respaldo. $O$ homem não é uma espécie singular, isento das ações da natureza (WORSTER, 2003, apud BANDEIRA, 2015). Assim, novas percepções surgem e com elas, a necessidade de se repensar a relação dos centros urbanos com suas águas.

A busca pelo equilíbrio nessa relação pode ser constatada através de diversos exemplos de modificação da paisagem urbana através da requalificação de rios e córregos (alguns foram mostrados no item 3.1 deste trabalho). Muitas dessas ações não se limitam a recuperar a qualidade das águas, mas a reintroduzi-las nos espaços urbanos, regatando seu significado simbólico, suas memórias e destacando os serviços que as águas prestam à cidade. Apesar dos casos de sucesso, é preciso estar consciente 
que essa nova compreensão a respeito das águas urbanas ainda está em estágio embrionário, pois não há políticas públicas que incentivem a aproximação da população e o cuidado da mesma para com os cursos d'água e, por consequência, ainda são frequentes as reivindicações para que os rios e córregos degradados sejam escondidos. Entretanto, as iniciativas existentes são fatores fundamentais para que as transformações ocorram e, conforme aponta Bandeira, vale a pena destacá-las para que "cada vez mais ganhem espaço e fomentem reflexões e intervenções mais conjuntas com a dinâmica ambiental" (BANDEIRA, 2015, p. 77).

\section{CONSIDERAÇÕES FINAIS}

O presente trabalho buscou promover a reflexão a respeito das transformações na relação das cidades com seus rios. Como visto, essa relação se molda através do sistema de crenças e valores de cada época, assim como, em muitos momentos, a própria sociedade é moldada por esta relação, em um constante movimento dialético. Fica clara, assim, a impossibilidade de se discutir o território (e seus elementos) sem a sua respectiva historicidade e, exatamente por isso, construir essas articulações não é uma tarefa simples. No entanto, tais aproximações contribuem para o maior entendimento das nuances dessa relação e, com isso, possibilita o estabelecimento de novas abordagens, quer que seja pesquisa ou prática.

O primeiro estudo de caso, o córrego Cheong-Gye, abordou uma intervenção drástica, cujos reais motivos para sua implementação não se pautaram pelo caráter ecológico. O intuito de trazer esse exemplo foi fazer um contraponto ao caso brasileiro e, principalmente, demonstrar que intervenções deste tipo são válidas pela possibilidade de promover debates fora do circuito acadêmico.

O caso do córrego Pirarungáua, foco principal deste trabalho, foi escolhido por seu pioneirismo na implementação de infraestrutura verde associada ao destamponamento de córregos. Sobre esta questão, há um ponto importante a ser tratado. É necessário ter em mente que o Pirarungáua se situa dentro de uma área de preservação e, consequentemente, não sofre diretamente os impactos da urbanização, diferentemente de córregos que correm em meio a áreas ocupadas, em especial os assentamentos precários situados nas bordas da cidade. Outro fator de diferenciação é caracterizado pelo próprio parque onde o córrego nasce, o Parque Estadual das Fontes do Ipiranga. 
Este é dotado de formações extremamente significativas, sendo destinado a conservação de espécies da flora nativa brasileira, bem como a abrigar populações da fauna característica da Mata Atlântica. O caráter do parque não é o lazer e a recreação dos habitantes, embora conte com atrativos neste sentido, e, mesmo estando envolto por área urbana consolidada, em muito se difere de parques como o lbirapuera ou o Parque da Luz. Isso posto, pode-se afirmar que a requalificação do córrego é um caso de sucesso, mas são necessários alguns cuidados para tomá-lo como modelo a ser replicado. Em meio a áreas urbanas, o desafio será certamente maior.

Sobre a questão central do trabalho, a caminhada apenas se inicia, mas se mostra promissora.

\section{REFERÊNCIAS}

BANDEIRA, Camila Martins da Silva. Expedição pelo riacho do Ipiranga: história, ciência e ambiente na educação. 2015. 285 f. Dissertação (Mestrado) - Curso de Educação, Faculdade de Educação, Universidade de São Paulo, São Paulo, 2015.

BLOG AMIGO PAI. Economia no Egito Antigo. 8 jun. 2015. Disponível em: <https://amigopai.wordpress.com/2015/06/08/economia-no-egito-antigo>. Acesso em 03 jun. 2018

CONDEPEFI. Conselho de Defesa do Parque Estadual das Fontes do Ipiranga (São Paulo). Secretaria Estadual do Meio Ambiente. Jardim Botânico de São Paulo comemora 80 anos. Disponível em: <http://www.condepefi.sp.gov.br/noticias/80_anos_botanico/jardim_botanico_80_anos.htm>. Acesso em: 20 maio 2018.

CONDEPEFI. Conselho de Defesa do Parque Estadual das Fontes do Ipiranga (São Paulo). Secretaria Estadual do Meio Ambiente. Saiba mais sobre o Parque Estadual das Fontes do Ipiranga. Disponível em: <http://www.condepefi.sp.gov.br/historico_pefi/historico_fontes_ipiranga.htm>. Acesso em: 20 maio 2018.

EXPEDIA. Pictures of World. Disponível em: <www.expedia.com/pictures/seoul/cheonggyecheonstream.d6159314/>. Acesso em 02 jun 2018.

FRANCO, Maria de Assunção Ribeiro. Planejamento ambiental para a cidade sustentável. 2. ed. São Paulo: Annablume: FAPESP, 2001. 296 p. Ilustrado.

GORSKI, Maria Cecília Barbieri. Rios e Cidades: ruptura e reconciliação. São Paulo: Editora Senac São Paulo, 2010. 300 p. 
GOVERNO DO ESTADO DE SÃO PAULO. Histórico do Jardim Botânico. Disponível em: <http:// jardimbotanico.sp.gov.br/o-jardim/historico-do-jardim-botanico/>. Acesso:20 maio 2018.

IBGE. Coordenação de Recursos Naturais e Estudos Ambientais. Manual Técnico da Vegetação Brasileira: sistema fitogeográfico : inventário das formações florestais e campestres : técnicas e manejo de coleções botânicas : procedimentos para mapeamentos. IBGE: Rio de Janeiro, 2012. 272p.

INSTITUTO DE BOTÂNICA. Plano de Manejo. Resumo executivo. Elaborado em junho de 2007.

LEE, In-keum. Cheong Gye Cheon Restoration Project: a revolution in Seoul. Seoul: Seoul Metropolitan Government, 2006. 63 slides, color, $28 \mathrm{~cm}$ x $21 \mathrm{~cm}$. Disponível em: <https://seoulsolution.kr/en/ node/2374>. Acesso em: 30 maio 2018.

MARX, Burle. Arte \& paisagem: conferências escolhidas. São Paulo: Studio Nobel, 2004. 224p.

NAMU MOE. Cheonggyecheon (em coreano). Disponível em: <https://namu.moe/ w/\%EC\%B2\%AD\%EA\%B3\%84\%EC\%B2\%9C>. Acesso em 02 jun 2018.

PEOPLE AND COUNTRIES. Jardins Suspensos da Babilônia (original em russo). 07 jul. 2015. Disponível em: <http://peopleandcountries.com/article-4865-1.html>. Acesso em 03 jun. 2018

PREFEITURA MUNICIPAL DE SÃO PAULO. Portal Geosampa. Disponível em: <http://geosampa. prefeitura.sp.gov.br> Acesso em: 31 maio 2018.

RAMALHOSO, Wellington. É possível devolver um rio à cidade? Notícias UOL. São Paulo, 29 fev. 2016. Disponível em: <https://noticias.uol.com.br/cotidiano/ultimas-noticias/2016/02/29/e-possivel-devolver-um-rio-a-cidade.htm>. Acesso em 20 maio 2018

REIS, Lucimara Flávio; SILVA, Rodrigo Luiz Medeiros da. Decadência e renascimento do Córrego Cheong-Gye em Seul, Coreia do Sul: as circunstâncias socioeconômicas de seu abandono e a motivação política por detrás do projeto de restauração. urbe, Revista Brasileira de Gestão Urbana, Curitiba, v. 8, n. 1, p. 113-129, Apr. 2016. Disponível em: <www.scielo.br/scielo.php?script=sci_arttext\&pid=S217533692016000100113\&lng=en\&nrm=iso>. Acesso: 15 Apr. 2018.

ROCHA, Yuri Tavares; CAVALHEIRO, Felisberto. Unidades de paisagem do Jardim Botânico de São Paulo. GEOUSP: Espaço e Tempo (Online), São Paulo, n. 7, p. 91-116, jun. 2000. ISSN 2179-0892. Disponível em: <http://www.revistas.usp.br/geousp/article/view/123406/119725>. Acesso em: 26 maio 2018.

ROCHA, Yuri Tavares; CAVALHEIRO, Felisberto. Aspectos históricos do Jardim Botânico de São Paulo. Revista Brasileira de Botânica, São Paulo, v. 24, n. 4, supl. p. 577-586, dez. 2001. Disponível em: $<$ http://www.scielo.br/scielo.php?script=sci_arttext\&pid=S0100-84042001000500013\&lng=en\&nrm=i so>. Acesso: 29 maio 2018. 
ROWE, Peter G. Os resultados e a história do projeto de restauração do Cheonggyecheon, em Seul, que derrubou uma via expressa elevada e propôs um espaço de lazer em torno ao córrego. Revista AU, edição 234, setembro de 2013. disponível em: <http://au17.pini.com.br/arquitetura-urbanismo/234/ restauracao-do-cheonggyecheon-seul-coreia-do-sul-296126-1.aspx>. Acesso em 01 jun 2018.

SARAIVA, Maria da Graça Amaral Neto. O rio como paisagem: gestão de corredores fluviais no quadro do ordenamento do território. Lisboa: Fundação Calouste Gulbenkian: Fundação para a Ciência e Tecnologia, Ministério da Ciência e Tecnologia, 1999. 512 p. Ilustrado.

SEOUL METROPOLITAN GOVERNMENT. Cheonggyecheon (Stream) around 1890. 18 mar. 2009a. Disponível em: <http://english.seoul.go.kr/chongguechon-around-1890/?cp=3\&cat=804>. Acesso em 02 jun 2018.

SEOUL METROPOLITAN GOVERNMENT. Cheonggyecheon (Stream) being covered in the 1950s. 18 mar. 2009b. Disponível em: <http://english.seoul.go.kr/chonggyechon-bing-covered-in-the1950039s/?cp=2\&cat=804>. Acesso em 02 jun 2018.

SIMATUPANG, Tasya. Cheonggyecheon jadi inspirasi untuk percantik sungai di Indonesia. 14 set. 2018. Disponível em: <https://beritagar.id/artikel/berita/cheonggyecheon-jadi-inspirasi-untuk-percantiksungai-di-indonesia>. Acesso em 22 set. 2018. 